Journal Article

\title{
Characterization of the polysaccharide from cola millenii seeds
}

Nwokocha, Louis M. and Williams, Peter A.

This article is currently is published by Elsevier. The definitive version of this article is available at: https://www.sciencedirect.com/science/article/pii/S0141813020335091

\section{Recommended citation:}

Nwokocha, Louis M. and Williams, Peter A. (2020) 'Characterization of the polysaccharide from cola millenii seeds', International Journal of Biological Macromolecules, vol 161, pp 643-647. Available online 11 June 2020. doi: 10.1016/j.ijbiomac.2020.06.068 
2 Louis M. Nwokocha ${ }^{1}$; Peter A. Williams ${ }^{2, *}$

3

$4 \quad{ }^{1}$ Department of Chemistry, University of Ibadan, Ibadan, Nigeria

$5{ }^{2}$ Center for Water Soluble Polymers, Wrexham Glyndwr University, Wrexham, LL 11 2AW,

$6 \quad$ North Wales, UK

$7 \quad *$ Corresponding author: Email: p.a.williams@glyndwr.ac.uk

8

9 ABSTRACT.

10 We have isolated and characterized a water soluble polysaccharide from Cola millenii seeds. It

11 was found to be composed of a total of 59\% neutral sugars (mainly rhamnose, galactose and

12 arabinose $\sim 24,13$ and $8 \%$ respectively) and $41 \%$ uronic acids [mainly galacturonic acid]. The

13 weight and number average molar mass values were found to be $4.7 \times 10^{6} \mathrm{~g} / \mathrm{mol}$ and $3.5 \times 10^{6}$

$14 \mathrm{~g} / \mathrm{mol}$, respectively. The polysaccharide exhibited polyelectrolyte properties with the intrinsic

15 viscosity varying with salt concentration. The polysaccharide formed a highly viscous solution in

16 water with apparent zero shear viscosities of $0.59-772 \mathrm{~Pa}$.s at concentrations $0.3-2.5 \mathrm{wt} \%$. The

17 solutions were shear thinning even at very low concentrations. The mechanical spectra showed

18 gel-like characteristics at concentrations $>2 \mathrm{wt} \%$. The rheological behavior indicates the

19 polysaccharide has potential for application as a thickener and suspending agent in food,

20 pharmaceutical and cosmetic formulations.

21 Key words: Cola millenii, polysaccharide, sugar composition, molar mass, rheological

22 properties, polyelectrolyte

23 1. INTRODUCTION 
24 Cola millenii $\mathrm{K}$ Schum is a leguminous plant belonging to the family Sterculiaceae and genus

25 Cola. It is a rain forest plant found in West Tropical Africa including Cote d'Ivoire, Southern

26 Nigeria, Ghana, Togo and Benin. It is a vigorously growing tree or shrub which may attain to a

27 height of 12-20 m and bears edible fruits with characteristic sweetness [1,2]. It is called monkey

28 kola in English. The pods may contain one to as many as eleven seeds per pod. Studies on

29 different parts of the plant have shown that the plant has antioxidant and antimicrobial activity [2,

$303,4]$. The chemical composition highlighting the nutritional, anti-nutritional and mineral elements

31 in $C$. millenii seed has been reported $[1,3,5]$. These authors have found that the seed has a

32 carbohydrate content of $28.73-51.54 \%$. Literature on the composition of $C$. millenii seed is scant.

33 Our previous study showed that $C$. millenii seed is rich in a water soluble polysaccharide [6]. In

34 this study we report its monosaccharide and protein composition, molecular mass distribution, and

35 rheological properties.

\section{MATERIALS AND METHODS}

\subsection{Isolation of Polysaccharide}

The Cola millenii pods were harvested wild from a forest in Ondo State Nigeria. About ten matured pods were collected from three plants. The pods (Figure 1) were cut and the seeds removed and air dried under ambient conditions. The seed coats were removed and the resulting endosperm pulverized and defatted with n-hexane for 8 h. $50 \mathrm{~g}$ defatted seed endosperm powder was dispersed in $400 \mathrm{~mL}$ distilled water and the water soluble polysaccharide extracted at room temperature under constant agitation for $2 \mathrm{~h}$. The dispersion obtained was poured into centrifuge

44 tubes and centrifuged at $2500 \mathrm{rpm}$ for $2 \mathrm{~h}$. The supernatant was decanted into a clean container and the residue reconstituted with $200 \mathrm{~mL}$ distilled water, agitated for the same period of time and centrifuged again. The combined supernatant was treated with excess isopropanol (1:4, v/v) 
47 to precipitate the polysaccharide. This was reconstituted in a small amount of water and poured

48 into round bottom flasks, frozen and freeze dried.

\section{$49 \quad 2.2$ Protein Determination}

50 The total nitrogen content of the sample was determined by the micro-Kjeldahl digestion and

51 distillation method. The nitrogen was converted to protein by multiplying by a factor of 6.25 .

\section{$52 \quad$ 2.3 Sugar Composition}

53 The sugar composition was determined by HPAEC-PAD using a Dionex ICS-2500 system.

54 Sugar analysis was by methanolysis followed by TFA hydrolysis using myo-inositol as internal 55 standard as reported previously [7].

\section{$56 \quad 2.4$ Molar mass distribution}

57 The molar mass was determined using Gel Permeation Chromatography using multiangle light 58 scattering, refractive index and UV absorbance (wavelength $=280 \mathrm{~nm}$ ) detectors (Optilab DSP, 59 Wyatt Technology Corporation, Santa Barbara Ca93103). The polysaccharide solution (2 $60 \mathrm{mg} / \mathrm{mL}$ ) prepared as described in Nwokocha \& Williams [8] was filtered through a $0.45 \mu \mathrm{m}$ 61 syringe and injected through a rheodyne into a $200 \mu \mathrm{L}$ loop connected to a combination of

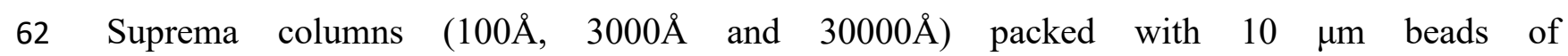
63 polyhydroxymethacrylate copolymer. The solvent was $0.1 \mathrm{M} \mathrm{NaNO}$ containing $10^{-6} \mathrm{M} \mathrm{NaN}$ 64 which was pumped (Waters: 515 HPLC Pump, Milford, MA 01757, USA) through a degasser 65 (CSI 6150, Cambridge Scientific Instruments, England) at a flow rate of $0.5 \mathrm{~mL} / \mathrm{min}$. The total 66 injected mass was $400 \mu \mathrm{g}$. The molecular mass distribution was analyzed with Astra software 67 (ASTRA 4.08.09) using the Berry method and a dn/dc value of $0.140 \mathrm{~mL} / \mathrm{g}$. 


\subsection{Rheological Measurements}

69

70

71

72

73

74

75

76

77

78

79

80

81

82

83

84

\subsubsection{Capillary viscometry}

Cola millenii polysaccharide $(0.15 \mathrm{~g} / 100 \mathrm{~mL})$ solution was prepared in different concentrations of $\mathrm{NaCl}(0.1 \mathrm{M}, 0.2 \mathrm{M}, 0.25 \mathrm{M}) .7 \mathrm{~mL}$ of the solution was poured into a capillary viscometer (Type: Cannon 75, J379) and placed in a thermostatic water bath maintained at $25^{\circ} \mathrm{C}$ to equilibrate. The flow time was measured in triplicate and the average taken.

Serial isoionic dilution was performed in situ for each salt concentration and readings were taken for each dilution. Similar measurements were made for the solvents alone and used to determine the relative viscosity as $\eta_{\mathrm{r}}=\mathrm{t} / \mathrm{t}_{\mathrm{s}}$. Where $\mathrm{t}=$ flow time of polysaccharide solution at each dilution and salt concentration, $\mathrm{t}_{\mathrm{s}}=$ flow time of solvent salt solution. The specific viscosity, $\eta_{\mathrm{sp}}$, was determined as $\eta_{\mathrm{sp}}=\eta_{\mathrm{r}}-1$. The intrinsic viscosity, $[\eta]$, was determined using the viscometric equations of Fedors $\left(1 / 2\left(\eta_{\mathrm{r}}^{1 / 2}-1\right)\right.$ versus $\left.1 / \mathrm{c}\right)$, Huggins $\left(\eta_{\mathrm{sp}} / \mathrm{c}\right.$ versus $\left.\mathrm{c}\right)$ and Kraemer $\left(\ln \left(\eta_{\mathrm{r}}\right) / \mathrm{c}\right.$ versus c); where $\mathrm{c}$ is polysaccharide concentration.

\subsubsection{Shear flow and oscillatory measurements}

The polysaccharide solutions $(0.3-2.5 \mathrm{wt} \%)$ were prepared by dissolving the polysaccharide powder in water at room temperature on a roller mixer (Staurt instruments, UK) overnight. The flow and oscillatory measurements were carried out on a Controlled Stress Rheometer (AR 2000, TA Instruments, USA) at $25^{\circ} \mathrm{C}$ using a $40 \mathrm{~mm}$ crosshatched steel plate (994387) for solutions 0.75-2.5wt\% and standard-size recessed end concentric cylinders geometry for solutions 0.3 $0.5 \mathrm{wt} \%$. A solvent trap was used in each measurement to minimize moisture loss. In the steady shear measurements the sample was subjected to a stepped flow over a shear rate range of 0.001$1000 \mathrm{~s}^{-1}$. For oscillatory measurements, an oscillation stress sweep was carried out at $1 \mathrm{~Hz}$ to 
90 locate the linear viscoelastic region. This was followed by a frequency sweep from $0.001-628$

$91 \mathrm{rad} / \mathrm{s}$ using an oscillation stress value in the linear viscoelastic region. The rheological data was

92 analyzed with Rheology Advantage Data Analysis.

\section{RESULTS AND DISCUSSION}

\section{$94 \quad 3.1$ Yield and Composition}

95 The water soluble polysaccharide in Cola millenii was extracted at a yield of 7.4\%. The 96 endosperm residue was still mucilaginous suggesting all the polysaccharide present could not be

97 extracted by the procedure used. The polysaccharide had a protein content of $10.7 \%$. This is 98 comparable to $11.69 \%$ protein reported for Mucuna flagellipes polysaccharide [9] and 6.9-10.3\% 99 reported for LBG [10].

100 The monosaccharide composition of the Cola millenii seed (Table 1) in order of abundance was 101 galacturonic acid (39.99\%), rhamnose (24.24\%), galactose (12.98\%), arabinose (7.59\%), glucose $102(5.08 \%)$, xylose (4.76\%), fucose (4.10\%) and glucuronic acid (1.26\%). Mannnose was not 103 detected in the polysaccharide. The high uronic acid content $(41.25 \%)$ of the C. millenii 104 polysaccharide indicates it would have polyelectrolyte properties. It also could crosslink with 105 calcium ions or other divalent cations to form a polysaccharide hydrogel [11].

\section{$106 \quad 3.2$ Molecular Mass Distribution}

107 The refractive index elution profiles of $C$. millenii polysaccharide are presented in Figures $2 \mathrm{a}$ and 108 2b. Figure 2a also shows the $M_{w}$ of the eluting species and Figure $2 b$ shows the radius of 109 gyration. 
110 The elution peak gave a strong light scattering signal but no UV signal at an absorbance of

$111280 \mathrm{~nm}$ [data not shown]. It is evident, therefore, that this peak corresponds to the elution of

112 polysaccharide material and does not contain any proteinaceous moieties. The weight average

113 molar mass, $M_{w}$, was found to be $4.7 \pm 0.2 \times 10^{6} \mathrm{~g} / \mathrm{mol}$ and the number average molar mass, $M_{n}$,

114 was $3.5 \pm 0.3 \times 10^{6} \mathrm{~g} / \mathrm{mol}$. The average radius of gyration, $R_{\mathrm{g}}$, was $106.8 \pm 0.8 \mathrm{~nm}$ (Table 2 ).

\section{$115 \quad 3.3$ Intrinsic Viscosity}

116 In Table 3, the intrinsic viscosity values of $C$. millenii polysaccharide were determined by the

117 Fedors, Huggins and Kraemer equations at different $\mathrm{NaCl}$ concentrations. The [ $\eta$ ] of the 118 polysacchaide was sensitive to salt concentration and decreased with increasing $\mathrm{NaCl}$ 119 concentration. This observation is consistent with the high uronic acid composition of the $C$. 120 millenii polysaccharide. In aqueous solution in the absence of electrolyte, the polysaccharide 121 uronic acids ionise leading to intramolecular repulsions resulting in chain expansion and an 122 increase in hydrodynamic volume. In the presence of added $\mathrm{NaCl}$, the intramolecular repulsions 123 are screened resulting in a decrease in the hydrodynamic volume. This is typical polyelectrolyte

124 behaviour [12]. The relationship between intrinsic viscosity and ionic strength for 125 polyelectrolytes in solution is given by Eq. 1

$126 \quad[\eta]=[\eta]^{\infty}+S I^{-1 / 2} \quad$ (Eq. 1)

127 where $[\eta],[\eta]^{\infty}$ are the intrinsic viscosity and intrinsic viscosity at infinite ionic strength, $\mathrm{I}^{-1 / 2}$ is 128 the inverse square root of ionic strength, $S$ is related to the polymer stiffness. From the plot of [ $\eta]$ 129 against $\mathrm{I}^{-1 / 2}$ (Figure 3), the intrinsic viscosity at infinite ionic strength was extrapolated to be 7.6 $130 \mathrm{dL} / \mathrm{g}$. This represents the hydrodynamic volume of the uncharged molecule. 
131 Smidsrod and Haug [13] defined the stiffness parameter (B) (Eq 2) which compares the chain

132 flexibility of different polyelectrolytes at fixed ionic strength $(0.1 \mathrm{M} \mathrm{NaCl})$.

$133 S=B\left([\eta]_{0.1 M}\right)^{v} \quad$ (Eq. 2)

134 Where $[\eta]_{0.1 \mathrm{M}}=10.8 \mathrm{dL} / \mathrm{g}$, the average intrinsic viscosity at $0.1 \mathrm{M} \mathrm{NaCl}, \quad v$ is an exponent 135 experimentally determined to be $1.3 \pm 0.1$. B was calculated to be 0.015 for $C$. millenii 136 polysaccharide. The flexibility of $C$. millenii polysaccharide is comparable to the value of 0.022 137 reported for high guluronic acid alginate [14] and higher than the value of 0.005 reported for 138 xanthan gum [13].

\section{$139 \quad 3.4$ Apparent Viscosity}

140 Figure 4a shows the viscosity shear rate profiles of $0.3-2.5 \mathrm{wt} \%$ of Cola millenii polysaccharide 141 in water. The polysaccharide at these concentrations exhibited shear thinning profiles which can 142 best be described by the Cross model (Eq. 3).

$$
\frac{\eta-\eta_{\infty}}{\eta_{\circ}-\eta_{\infty}}=\frac{1}{1+(\tau \times \dot{\gamma})^{n}}
$$

145 Where $\eta, \eta_{o}$ and $\eta_{\infty}$ are viscosity (Pa.s), zero shear viscosity (Pa.s) and infinite shear viscosity 146 (Pa.s) respectively, $\bar{\gamma}$ is shear rate $\left(\mathrm{s}^{-1}\right), \tau$ is Cross relaxation time and $\mathrm{n}$ is the rate index 147 (dimensionless).

148 The parameters of the Cross model are shown in Table 4. The $\eta_{\mathrm{o}}$ ranged from 0.59 - 772 Pa.s and 149 increased as concentration increased. The onset of shear thinning (critical shear rate, $\breve{V}_{\text {crit }}$ ) shifted 150 to lower shear rates as the concentration increased. This is related to the Cross relaxation time $(\tau)$ 151 by $\left(\tau=1 / \bar{\gamma}_{\text {crit }}\right) ; \bar{\gamma}_{\text {crit }}$ marks the onset of shear thinning. The Cross rate index was in the range 
$1520.5603<\mathrm{n}<0.8633$ and increased with polysaccharide concentration. The low values of the

153 standard error of estimates (s.e <20) indicated that the Cross model adequately described the

154 flow properties of $C$. millenii polysaccharide.

155 The zero shear viscosity for a $0.5 \%$ solution was $\sim 1$ Pa.s which is similar to the zero shear 156 viscosity of xanthan gum at the same concentration reported by Sworn [15]. The high $\eta_{\mathrm{o}}$ of $C$.

157 millenii indicates its potential as a thickener and suspending agent for particulate dispersions and 158 emulsions.

159 Figure $4 \mathrm{~b}$ shows the plot of reduced viscosity $\left(\eta / \eta_{0}\right)$ versus Deborah number ( $\left.\tau \bar{\gamma}\right)$ for different 160 polysaccharide concentrations. A master curve was observed with deviation for some flow 161 profiles at higher values of Deborah number. As $\tau \bar{\gamma}$ tended to zero, $\eta / \eta_{0}$ approached unity. At 162 higher Deborah number, the flow profiles for those concentrations that approached terminal 163 viscosity deviated from the master curve. Similar deviations have been reported for other 164 polysaccharides at shear rates approaching infinity [16]. Figure 5 shows the plot of log zero shear 165 viscosity versus $\log$ concentration in the concentrated solution regime of C. millenii 166 polysaccharide. The viscosity dependence of concentration for $C$. millenii polysaccharide was 167 given by $\mathrm{c}^{3.3}$ which is in agreement with values reported by Morris, Cutler, Ross-Murphy, Rees 168 and Price [17] for conformational disordered polysaccharides in the concentrated regime.

$169 \quad 3.5$ Viscoelastic properties

170 Figure 6 shows the plot of the elastic $\left(\mathrm{G}^{\prime}\right)$ and loss $\left(\mathrm{G}^{\prime \prime}\right)$ moduli against angular frequency $(\omega)$ of 171 solutions of Cola millenii polysaccharide at different concentrations $(0.5,0.75,1,1.5,2$ and 2.5

$172 \mathrm{wt} \%$ ). Both $\mathrm{G}^{\prime}, \mathrm{G}^{\prime \prime}$ showed dependence on $\omega$ and the extent of dependence was a function of 173 concentration of the polysaccharide. 
174 For polysaccharide concentrations $0.5,0.75$ and $1 \mathrm{wt} \%, \mathrm{G}^{\prime \prime}>\mathrm{G}^{\prime}$ at lower $\omega$, both moduli 175 increased as $\omega$ increased but separation between them decreased until a critical frequency was 176 reached where both moduli crossed over at $\left(G^{\prime}=G^{\prime \prime}\right)$. Below this point the polysaccharide 177 solution exhibited liquid-like properties $\left(\mathrm{G}^{\prime \prime}>\mathrm{G}^{\prime}\right)$ but above this point the solution exhibited a 178 gel-like response $\left(G^{\prime}>G^{\prime \prime}\right)$. For 1.5 and $2 \mathrm{wt} \%$, at low $\omega, G^{\prime}$ and $G^{\prime \prime}$ were independent of $\omega\left(G^{\prime \prime}\right.$ $\left.179 \approx \mathrm{G}^{\prime}\right)$, however both moduli increased but $\mathrm{G}^{\prime}$ increased faster than $\mathrm{G}^{\prime \prime}$ until $\mathrm{G}^{\prime}>\mathrm{G}^{\prime \prime}$ indicating the 180 transition from liquid-like to a gel-like response. For a $2.5 \mathrm{wt} \%$ polysaccharide concentration, $\mathrm{G}^{\prime}$ $181>\mathrm{G}^{\prime \prime}$ all through the range of $\omega$ indicating the solution exhibited gel-like behavior. Table 5 shows 182 the variation of the critical angular frequency $\left(\omega_{\text {crit }}\right)$ and $G^{\prime} G^{\prime \prime}$ crossover point with 183 concentration. As polysaccharide concentration increased, the value of $G^{\prime} G^{\prime \prime}$ at the crossover 184 point increased while the value of $\omega_{\text {crit }}$ shifted to lower $\omega$. This observation is consistent with 185 random coil polymers [18].

\section{CONCLUSION}

187 The water-soluble polysaccharide extracted from Cola millenii seeds has a high molar mass and 188 forms highly viscous and viscoelastic solutions at low concentrations. It is evident that the zero 189 shear viscosity at $0.5 \%$ concentration has a similar magnitude to that for xanthan gum at the same 190 concentration and hence it has promise for application as suspending agent and stabilizer in food 191 and other formulations.

193 Acknowledgements: The authors acknowledge the award of a Leverhulme Trust Visiting 194 Fellowship to Dr Nwokocha. We are grateful to Dr M. Yadhav for carrying out the sugar analysis.

\section{5. REFERENCES}


197 [1]. F. B. Borokini, A. Abitogun \& E. G. Olumayede (2014). Nutritional, antinutritional and 198 antimicrobial activities of seed and pulp of Cola millenii. IOSR Journal of Applied Chemistry, $199 \quad 7(5), 113-118$.

200 [2]. O. T. Orisakeye \& A. A. Ojo (2013). Antimicrobial and antioxidant evaluation of various 201 parts of Cola millenii K. Schum plant. African Journal of Pharmacy and Pharmacology, 7(48), $202 \quad 3019-3025$.

203 [3]. I. A. Ajayi \& O. O. Ojelere (2013). Phytochemical analysis and mineral element composition 204 of ten medicinal plant seeds from South-West Nigeria. New York Science Journal, 6(9), 22-28.

205 [4]. O. E. Giwa, F. O. Onileke, I. A. Adesina \& V. T. Adebote (2012). Phytochemical and 206 antimicrobial properties of seed and pulp of monkey cola (Cola millenii) on some selected clinical 207 and food borne isolates. International Journal of Applied Biology and Pharmaceutical 208 Technology, 3(3), 390-400.

209 [5]. M. O. Bello, O. S. Falade, S. R. A. Adewusi \& N. O. Olawore (2008). Studies on the 210 chemical compositions and anti-nutrients of some lesser known Nigeria fruits. African Journal of 211 Biotechnology, 7(21), 3972-3979.

212 [6]. L.M. Nwokocha \& P. A. Williams (2012a). Evaluating the potential of Nigerian plants as a 213 source of industrial hydrocolloids. In Gums and Stabilizers for the Food Industry 16. P.A. 214 Williams, \& G.O. Phillips (Eds.), Royal Society of Chemistry, Cambridge, United Kingdom. pp. 215 27- 44.

216 [7]. S. Kokubun, M. P. Madhav. R. A. Moreau \& Williams, P. A. (2014). Components 217 responsible for the emulsification properties of corn fibre. Food Hydrocolloids, 41, 164-168. 
218 [8]. L.M. Nwokocha \& P. A. Williams (2012b). Rheological characterization of the 219 galactomannan from Leucaena leucocephala seed. Carbohydrate Polymers, 90, 833- 838.

220 [9]. L.M. Nwokocha \& P. A. Williams (2009). Isolation and rheological characterization of 221 Mucuna flagellipes seed gum. Food Hydrocolloids, 23, 1394-1397.

222 [10]. S.E. Gaisford, S. E. Harding, J. R. Mitchell \& T. D. Bradley (1986). A comparison 223 between the hot and cold water soluble fractions of two locust bean gum samples, Carbohydrate 224 Polymers, 6, 423-442.

225 [11]. H.U. Endress (2011). Pectins: Production, properties and applications. In Renewable 226 Resources for Functional Polymers and Biomaterials: Polysaccharides, Proteins and Polyesters. 227 P.A. Williams (Ed.), Royal Society of Chemistry, Cambridge, United Kingdom. pp. 210-248.

228 [12]. E. D. Vega, E. Vásquez, J. R. A. Diaz \& M.A. Masuelli (2015). Influence of the ionic 229 strength in the intrinsic viscosity of xanthan gum. An experimental review. Journal of Polymer 230 and Biopolymer Physics Chemistry, 3 (1), 12-18.

231 [13]. O. Smidsrod \& A. Haug (1971). Estimation of the relative stiffness of the molecular chain 232 in polyelectrolytes from measurements of viscosity at different ionic strengths. Biopolymers, 10, $233 \quad 1213-1221$.

234 [14]. A. Abodinar, A.M. Smith \& G.A. Morris (2014). Morris, A novel method to estimate the 235 stiffness of carbohydrate polyelectrolyte polymers based on the ionic strength dependence of zeta 236 potential. Carbohydrate Polymers, 112(6), 6-9.

237 [15]. G. Sworn (2009). Xanthan gum. In Handbook of Hydrocolloids, 2nd edition, G.O. Phillips 238 \& P.A. Williams (Eds.), Woodhead Publishing Ltd, Cambridge, United Kingdom. pp.186. 
239 [16]. L.M. Nwokocha \& P. A. Williams (2016). Rheological properties of a polysaccharide 240 isolated from Adansonia digitata leaves, Food Hydrocolloids, 58, 29 - 34.

241 [17]. E. R. Morris, A. N. Cutler, S. B. Ross-Murphy, D. A. Rees \& J. Price (1981).

242 Concentration and shear rate dependence of viscosity in random coil polysaccharide solutions.

243 Carbohydrate Polymers, 1, 5-21.

244 [18]. L.M. Nwokocha \& P. A. Williams (2014). Solution properties of Brachystegia eurycoma 245 seed polysaccharide. In Gums and Stabilizers for the Food Industry 17: The Changing Face of 246 Food Manufacture: The Role of Hydrocolloids. P.A. Williams, \& G.O. Phillips (Eds.), Royal 247 Society of Chemistry, Cambridge, United Kingdom. pp. 123-138. 
Table 1. Composition of Cola millenii polysaccharide

\begin{tabular}{ll}
\hline Monosaccharide & Relative mole $\%$ \\
\hline Fuc & 4.10 \\
Rham & 24.24 \\
Ara & 7.59 \\
Glc & 5.08 \\
Gal & 12.98 \\
Xyl & 4.76 \\
Man & 0.00 \\
GalA & 39.99 \\
GlcA & 1.26
\end{tabular}

Fuc, Fucose; Rham, Rhamnose; Ara, Arabinose; Glc, Glucose; Xyl, Xylose; Man, Mannose; GalA, galacturonic acid; GlcA, Glucuronic acid.

251

Table 2. Molecular mass parameters of Cola millenii polysaccharide

\begin{tabular}{ll}
\hline Parameter & Peak \\
\hline $\mathrm{M}_{\mathrm{w}}(\mathrm{g} / \mathrm{mol})$ & $4.7 \pm 0.2 \times 10^{6}$ \\
$\mathrm{M}_{\mathrm{n}}(\mathrm{g} / \mathrm{mol})$ & $3.5 \pm 0.3 \times 10^{6}$ \\
$\mathrm{M}_{\mathrm{w}} / \mathrm{M}_{\mathrm{n}}$ & $1.40 \pm 0.06$ \\
$\mathrm{R}_{\mathrm{g}}(\mathrm{nm})$ & $106.8 \pm 0.8$
\end{tabular}

$\mathrm{M}_{\mathrm{w}}=$ mass average molecular mass; $\mathrm{M}_{\mathrm{n}}=$ number average molecular mass,

$\mathrm{R}_{\mathrm{g}}=$ radius of gyration; $*$ Results are mean \pm std of two determinations 
Table 3. Intrinsic viscosity, [ ], of Cola millenii polysaccharide at different $\mathrm{NaCl}$ concentrations using different equations

\begin{tabular}{llll}
\hline $\mathrm{NaCl}(\mathrm{aq})$ & \multicolumn{2}{c}{$[\eta]$} \\
\hline $0.1 \mathrm{M}$ & Huggins & Kraemer & Fedors \\
\cline { 2 - 4 } $0.2 \mathrm{M}$ & 9.7 & 11.1 & 11.67 \\
$0.25 \mathrm{M}$ & 9.35 & 9.98 & 10.10 \\
\hline
\end{tabular}


Table 4. Parameters of shear viscosity versus shear rate at different concentrations Cola millenii polysaccharide according to Cross model

\begin{tabular}{llllll}
\hline Conc $(\mathrm{wt} \%)$ & $\eta_{\mathrm{o}}(\mathrm{Pa} \mathrm{s})$ & $\eta_{\infty}(\mathrm{Pa} \mathrm{s})$ & $\tau(\mathrm{s})$ & $\mathrm{n}$ & $\mathrm{s.e}$ \\
\hline 0.3 & 0.5864 & $7.047 \mathrm{E}-3$ & 4.51 & 0.5603 & 6.594 \\
0.5 & 2.023 & 0.01925 & 4.213 & 0.6988 & 19.45 \\
0.75 & 9.75 & 0.02823 & 9.506 & 0.7292 & 12.25 \\
1 & 21.25 & 0.02656 & 14.93 & 0.7335 & 8.555 \\
1.5 & 90.11 & 0.03711 & 38.31 & 0.7506 & 11.62 \\
2 & 177.1 & 0.0568 & 25.98 & 0.8178 & 9.978 \\
2.5 & & & & & \\
\hline
\end{tabular}

$\eta_{\mathrm{o}}, \eta_{\infty}=$ zero and infinite shear viscosity, respectively; $\tau=$ Cross relaxation time; $\mathrm{n}=$ rate index;

s.e. $=$ standard error 
Table 5. Parameters of oscillation at different concentrations Cola millenii polysaccharide

\begin{tabular}{lll}
\hline Conc. $(\mathrm{wt} \%)$ & $\omega_{\text {crit }}(\mathrm{rad} / \mathrm{s})$ & $\mathrm{G}(\mathrm{Pa})$ \\
\hline 0.50 & 0.3564 & 0.184 \\
0.75 & 0.0986 & 0.283 \\
1 & 0.06999 & 0.4066 \\
1.50 & 0.00681 & 0.5778 \\
2 & 0.003047 & 0.7083
\end{tabular}

$\omega_{\text {crit }}=$ angular frequency at crossover point $; \mathrm{G}=$ modulus at crossover
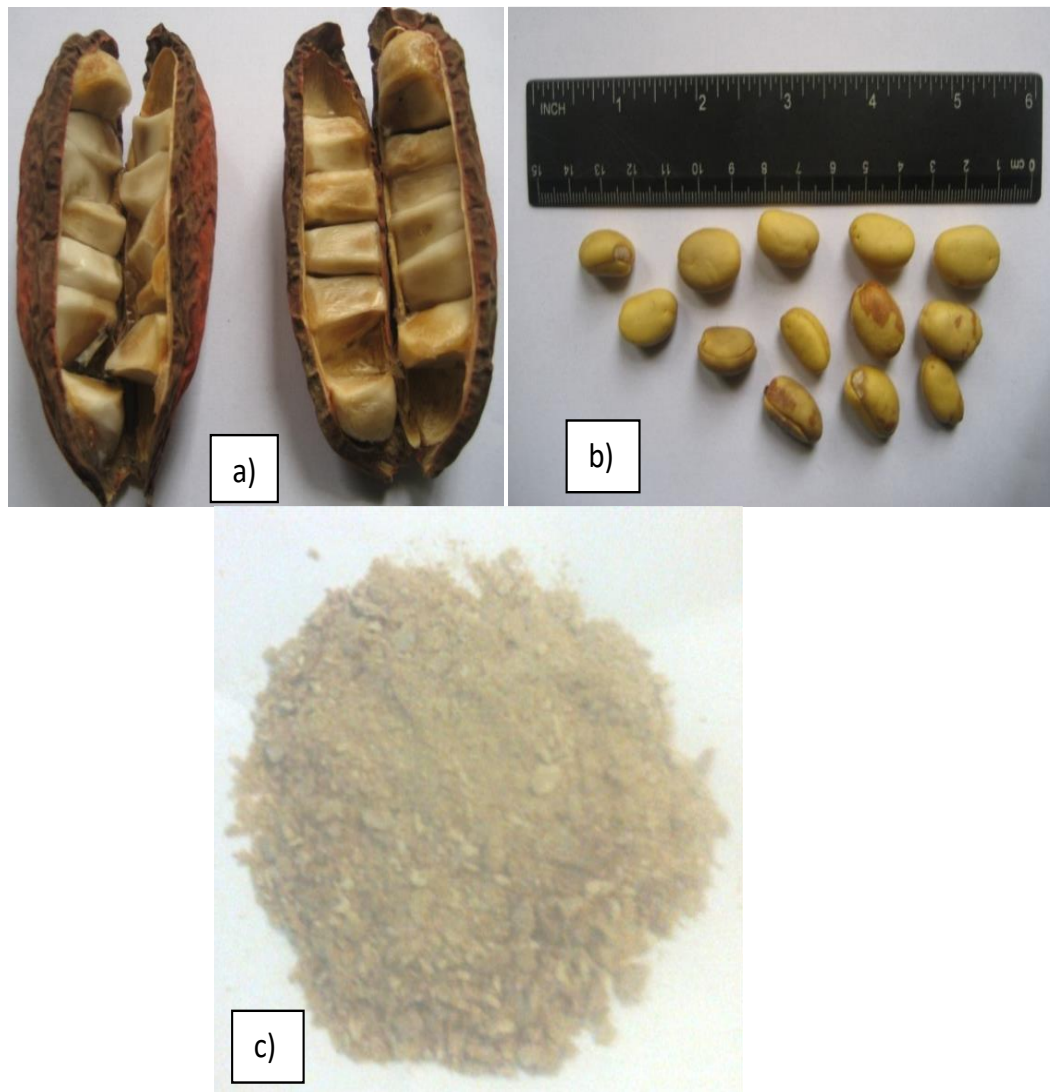

Figure 1. Cola millenii a) seed pods; b) seed endosperms; c). seed polysaccharide 


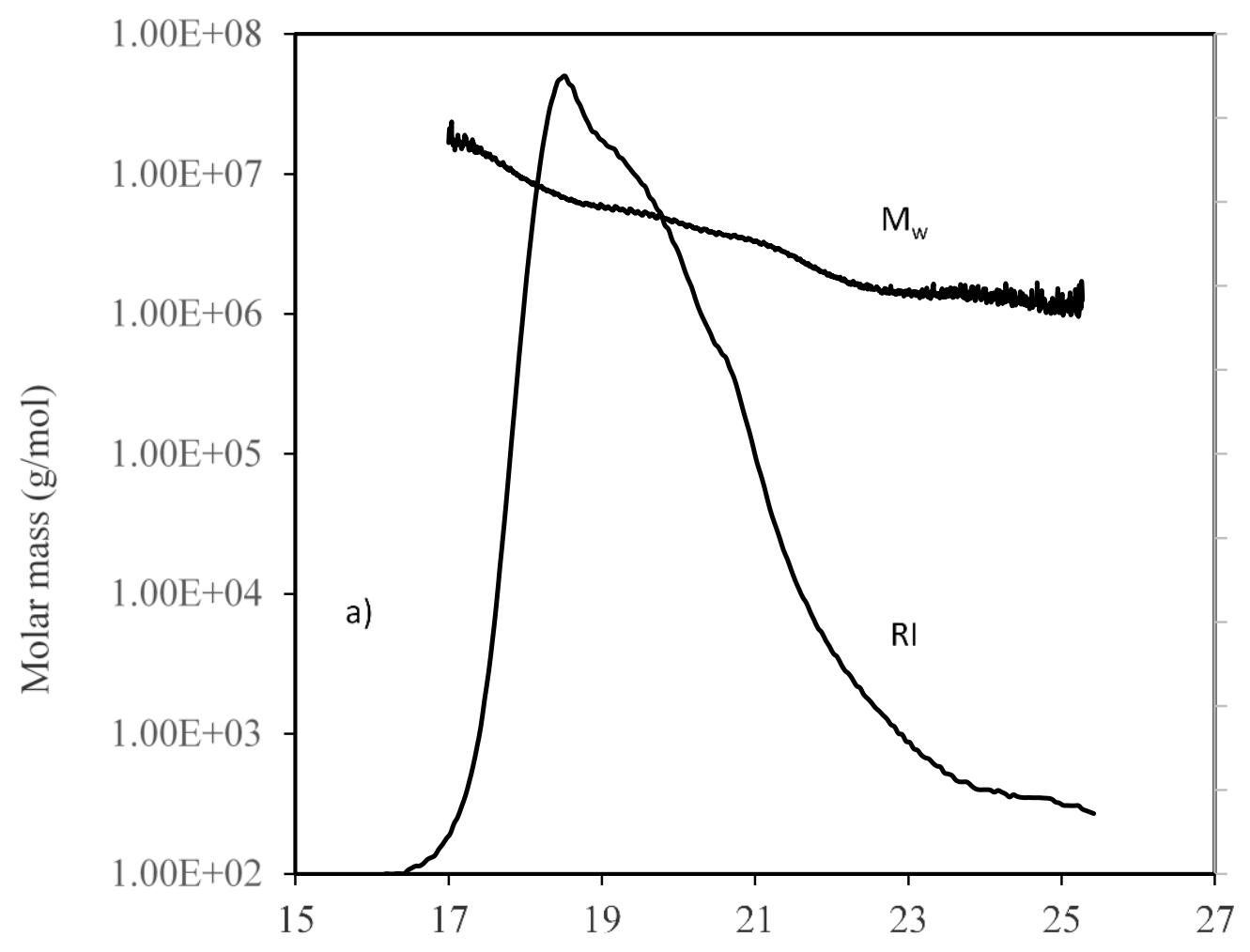

Elution volume $(\mathrm{mL})$

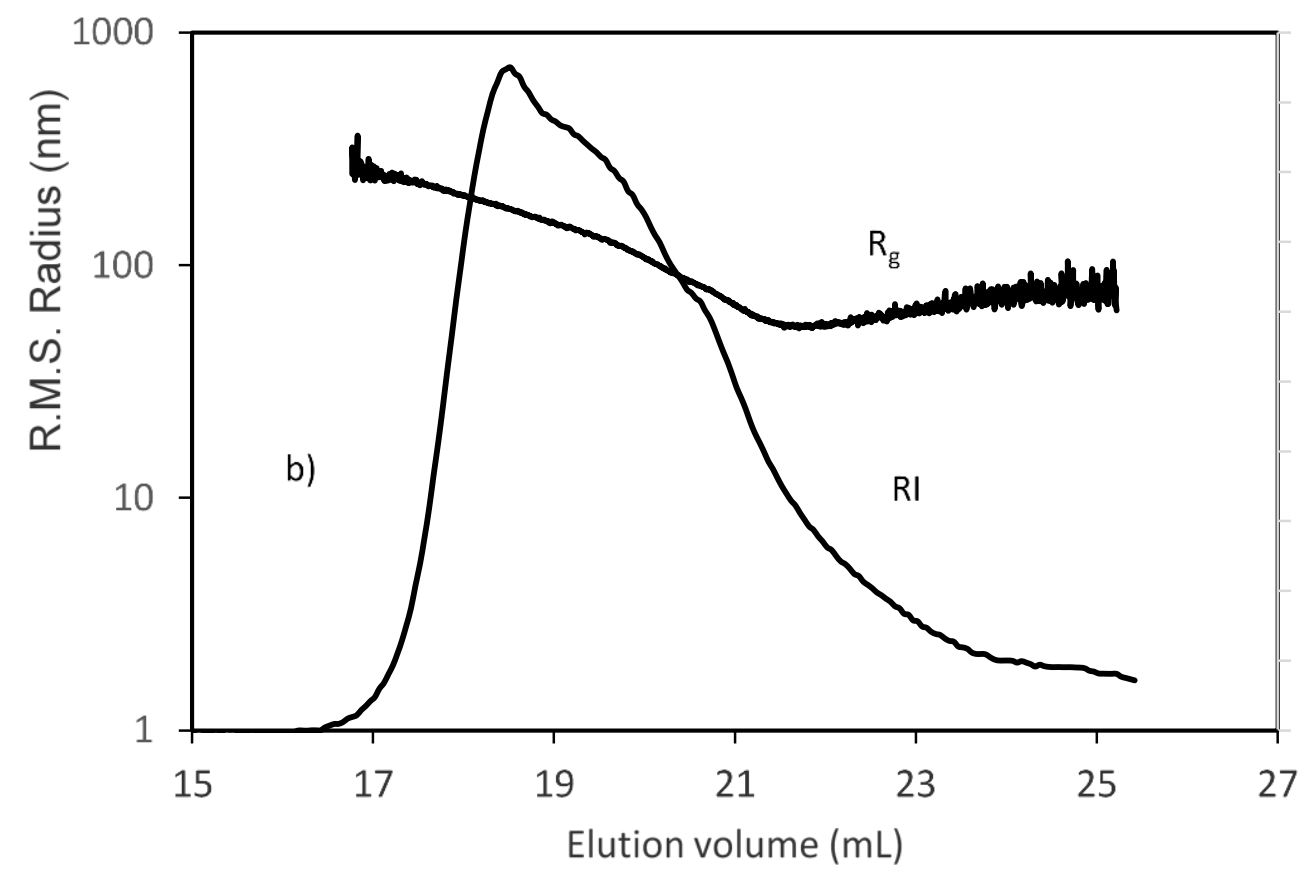

Figure 2. (a). Molar mass $\left(\mathrm{M}_{\mathrm{w}}\right)$ and Refractive index (RI) versus Elution volume; (b). R.M.S. radius ( $\left.\mathrm{R}_{\mathrm{g}}\right)$ and Refractive index (RI) versus Elution volume 

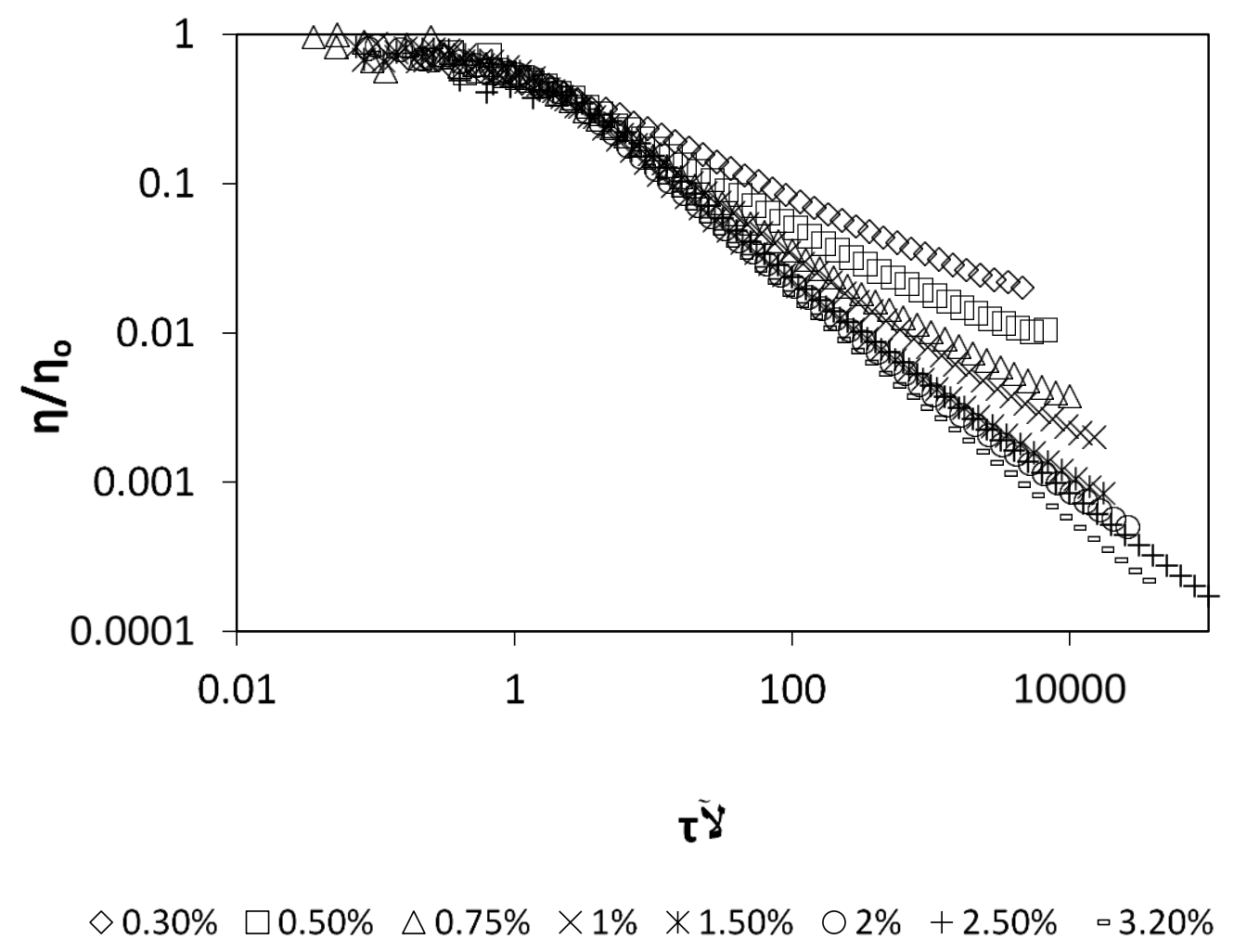

Figure 4b. Master curve: Reduced viscosity $\left(\eta / \eta_{\mathrm{o}}\right)$ versus Deborah number $(\tau \bar{\gamma})$

258

259 


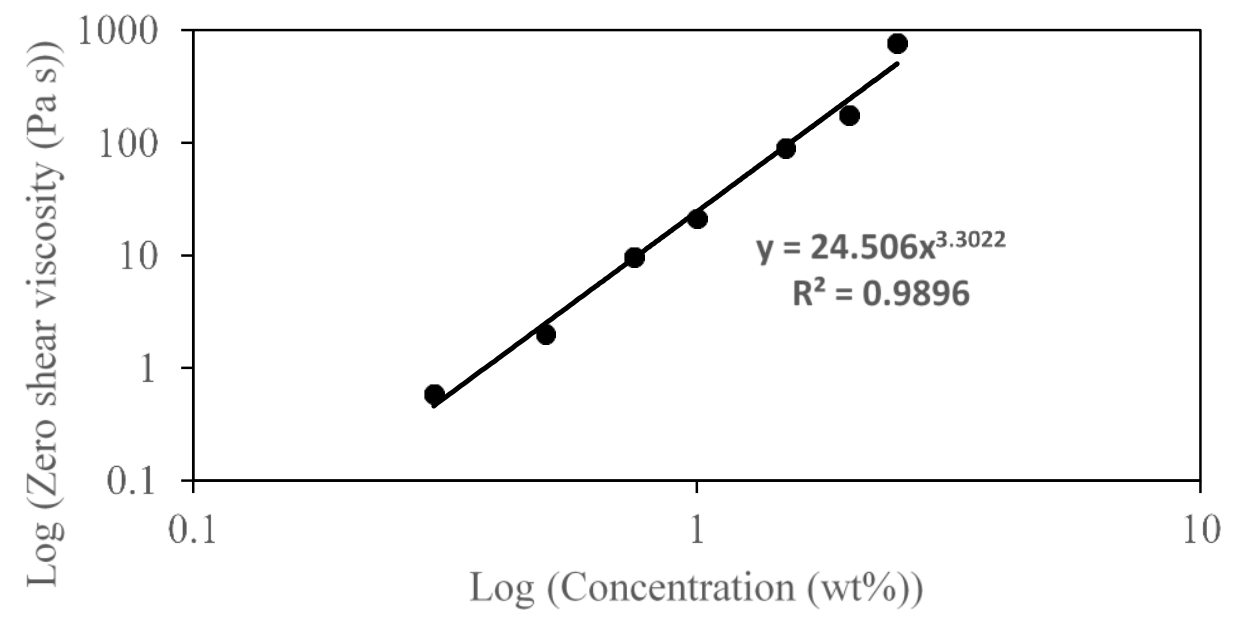

Figure 5. Log Zero shear viscosity versus Log Concentration

260

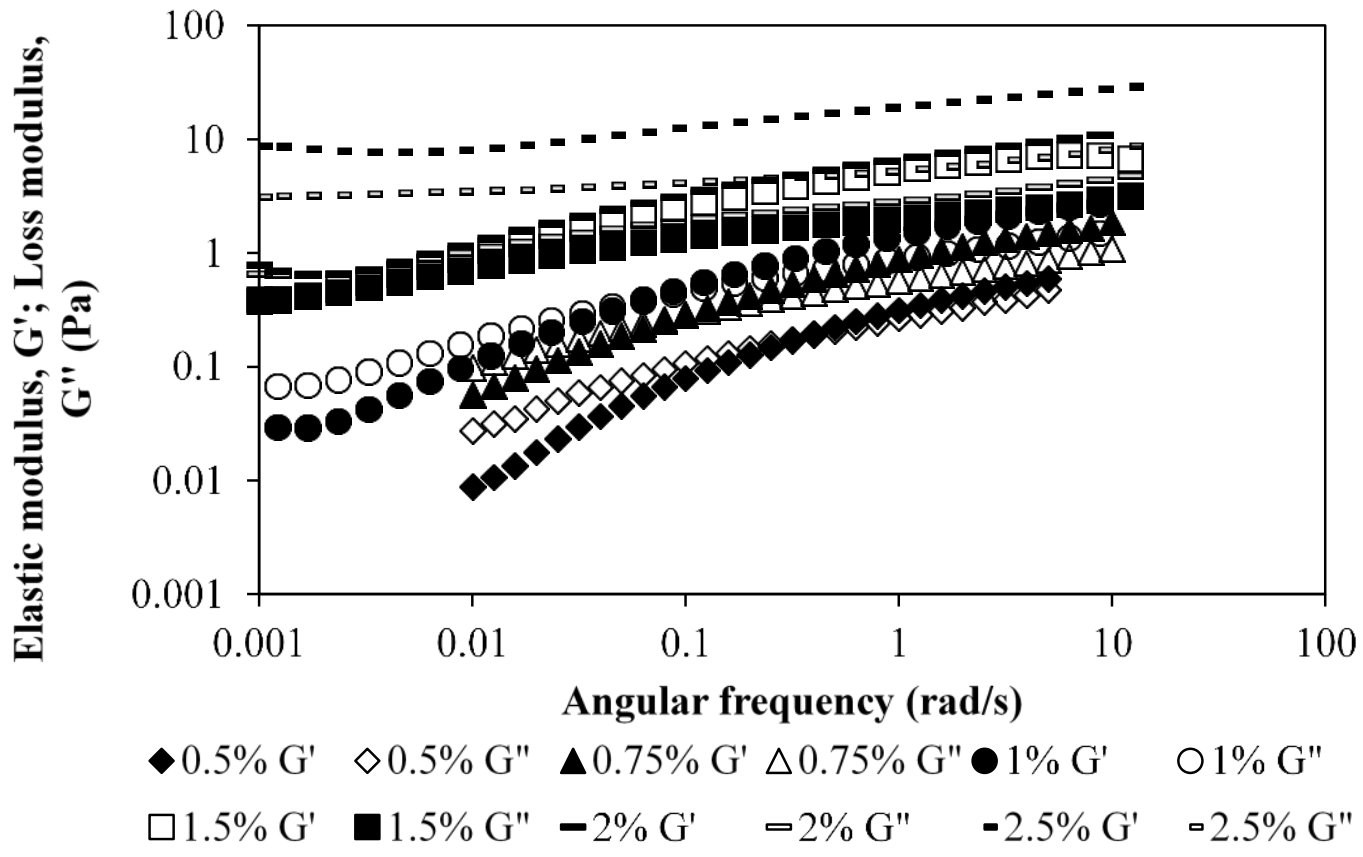

Figure 6. Elastic, $\mathrm{G}^{\prime}$ and loss, $\mathrm{G}^{\prime \prime}$ moduli versus angular frequency, $\omega$ 